\title{
The Economics of Silicon Applications on Rice and Sugarcane in Florida ${ }^{1}$
}

\author{
José Alvarez, Lawrence E. Datnoff, and George H. Snyder²
}

\section{Introduction}

Since the mid-1970s, silicon applications, first to sugarcane and later to rice-sugarcane rotations, have been used increasingly in the Everglades Agricultural Area (EAA) in Florida. Publications with economic analyses have complemented a growing literature in the physical and biological sciences. Because of the expenses involved in this cultural practice, questions about the profitability of the decision have always been present.

The first economic analysis of silicon (calcium silicate slag) applied to sugarcane in the EAA showed positive returns on investment (Alvarez and Gascho, 1979). After a rice industry was established in the EAA in 1977 and experiments proved that rice was responsive to silicon, the question of when to apply the silicon was investigated. Of the three potential times silicon can be applied (before rice, before sugarcane, or before rice-sugarcane rotation), the highest net returns were achieved when silicon was applied before planting rice in rice-sugarcane rotations (Alvarez, et al., 1988). Using both Florida and U.S. data, more analyses were conducted to investigate the economic potential of silicon for integrated management and sustainable rice and sugarcane production (Alvarez and Datnoff, 2001a; Alvarez and Datnoff, 2001b). Benefits from silicon applications to both crops include positive impacts on yields, better disease and insect management, savings in fungicide and insecticide costs from fewer applications, and reductions in fertilizer applications. Additional benefits, which were different for rice and sugarcane, were also identified.

The purpose of this document is to summarize previous economic information on silicon applications to rice and sugarcane in the EAA and to make this information available through EDIS. These summaries will be provided for monocultures of rice and sugarcane and for rice-sugarcane rotation production. Growers overwhelmingly use silicon applications for rice-sugarcane rotations in Florida.

1. This is EDIS document FE475, a publication of the Department of Food and Resource Economics, Florida Cooperative Extension Service, UF/IFAS, University of Florida, Gainesville, FL. Published May 2004. This publication is also part of the Florida Sugarcane Handbook, an electronic publication of the Department of Agronomy, University of Florida, Gainesville, FL. For more information, you may contact the editor of the Sugarcane Handbook, Dr. R.A. Gilbert (ragilbert@ifas.ufl.edu), Everglades Research and Education Center, University of Florida, Belle Glade, FL 33430. Please visit the EDIS website at http://edis.ifas.ufl.edu.

2. José Alvarez, Professor, Department of Food and Resource Economics; Lawrence E. Datnoff, Professor and Associate Center Director, Department of Plant Pathology; and George H. Snyder, Distinguished Professor, Department of Soil and Water Science, Everglades Research and Education Center, Belle Glade, FL, Florida Cooperative Extension Service, UF/IFAS, University of Florida.

The Institute of Food and Agricultural Sciences is an equal opportunity/affirmative action employer authorized to provide research, educational information and other services only to individuals and institutions that function without regard to race, color, sex, age, handicap, or national origin. For information on obtaining other extension publications, contact your county Cooperative Extension Service office. Florida Cooperative Extension Service/Institute of Food and Agricultural Sciences/University of Florida/Christine Taylor Waddill, Dean. 


\section{Benefits and Costs for Rice Production}

The following benefits are quantified for monoculture rice production: increased yields, disease control (including reduced grain discoloration), and insect management. Before showing the analyses, a series of assumptions is presented.

\section{General Assumptions and Data Sources}

Before the benefits and costs of monoculture rice production can be quantified, it is first necessary to make some preliminary assumptions. They include:

- Application rate: 1.11 tons per acre of calcium silicate slag (standard silicon grade from Calcium Silicate Corporation, Inc., Columbia, $\mathrm{TN}$ ), with a $20 \%$ silicon content, or 0.22 ton per acre, at a cost of $\$ 43.50$ per ton, effective for two years.

- Average rice yield: 2.23 tons per acre without silicon application.

Costs and prices were obtained in Florida from a rice mill located in the EAA and from dealers servicing local producers in mid-2003.

\section{Yields}

Yield increases-ranging from $4.6 \%$ to $48 \%$ - due to silicon applications have been clearly demonstrated (Savant, et al., 1997). A 12\% increase in rice yields translates into a 0.27 ton per acre increase each year. If the price of U.S. No. 2 rough rice is $\$ 220$ per ton, the extra gross revenue is $\$ 59.40$ per acre, and the silicon cost, including application, is $\$ 48.50$ per acre. The cost of harvesting and hauling the extra rice produced is $\$ 4.20$ per ton, or $\$ 1.13$ per acre $(\$ 4.2 \times 0.27)$. Thus the first-year extra net revenue is $\$ 9.77$ per acre $(\$ 59.40$ - $\$ 48.50$ - $\$ 1.13)$.

Calculating the extra net revenue for the second year of rice production requires the use of the $\$ 1$ (1 $+\mathrm{i})^{-\mathrm{n}}=\$ 1(1+0.08)^{-1.5}=0.891$ value formula, where $i$ is the interest rate (8\%) for income and $n$ is the number of years (1.5) until income is received. Thus the net revenue for the second year is $\$ 51.92$ per acre $[(\$ 59.40$ - \$1.13) x 0.891]. The total extra net revenue equals $\$ 61.69$ per acre, or $\$ 9.77$ for Year 1 and $\$ 51.92$ for Year 2 [Table 1].

\section{Diseases}

It has been demonstrated that silicon eliminates the need for fungicide in managing rice (Datnoff, et al., 1997). Following the same price-cost structure defined above, the first year's savings from two applications of fungicide, including the cost of materials and application, are $\$ 31.97$ per acre. The second year's savings are $\$ 28.48$ (\$31.97 x 0.891). Thus the total savings are $\$ 60.45$ per acre.

\section{Grain Discoloration}

Research has shown that silicon application, in addition to producing a healthier plant, provides better grain appearance. In Florida, it is widely recognized that silicon improves the quality of the rice grain, which translates into better grain milling and more whiteness per grain (Anonymous, 1997).

The penalty for moving from U.S. No. 2 to U.S. No. 3 rice, as a result of grain discoloration in the United States, is $\$ 10$ per ton at the reference price. When the quality increases from No. 3 to No. 2 due to silicon application for an estimated 2.23 tons of rice per acre, the added annual net return is $\$ 22.30$ per acre.

\section{Insects}

Silicon has the ability to greatly reduce the impact of several economically important insect pests (Savant, et al., 1997), which means fewer insecticide applications are needed. For example, when the cost of one application is $\$ 4.25$ per acre and the number of applications is reduced from three to one per crop, the total savings are $\$ 8.50$ per acre.

\section{Other Benefits}

In upland conditions, phosphate $(\mathrm{P})$ applications may be reduced every year. In acid soils where applications eliminate or reduce the need for liming, more savings can be obtained.

Several other benefits to rice crops with silicon applications have been documented in the literature. Some of the benefits have been difficult to quantify. Other benefits, if they could be quantified, may be the 
result of interrelated factors, which could lead to double-counting. For those reasons, they are not included in the numerical description of the benefits and costs. They should, however, be taken into consideration when evaluating the trade-off between the benefits from silicon applications and the high cost of materials. Epstein (2001, p. 10) lists the benefits as:

- Promotion of upright stature and resistance to lodging.

- Role in favorable exposure of leaves to light; hence promotion of photosynthesis.

- Effects on surface properties.

- Resistance to disease.

- Reistance to some insects and mammals.

- Resistance to toxic metals.

- Resistance to salinity stress.

- Reduction of drought stress.

- Protection against extreme temperatures.

- Effects on enzyme activities.

- Effects on mineral composition.

\section{Total Benefits}

Adding the net returns per acre generated by the extra yield (\$61.69), the savings from fungicide (\$60.45) and insecticide (\$8.50) applications, and improved potential grain discoloration $(\$ 22.30)$, the total extra net returns are $\$ 152.94$ per acre.

\section{Benefits and Costs for Sugarcane Production}

The only benefit that can be quantified is the impact on yields. Additional benefits reported in the literature have not been quantified, or the results are lacking. As in the case of rice, several assumptions are necessary.

\section{General Assumptions and Data Sources}

The assumptions include:

- The example pertains to a producer of administration cane (sugarcane grown by a corporation or cooperative members for use in their own mills), not to an independent producer.

- Application rate: 2.22 tons per acre of silicon (standard Si grade) at a cost of $\$ 43.50$ per ton, including application, effective for two years.

- Average yield: 40 net tons per acre, or 0.1075 ton of sugar per ton of sugarcane, assuming $14.27 \%$ sucrose in normal juice for the sugarcane plant crop, and 35 net tons per acre (same sugar assumption) for the first stubble crop.

Costs and prices were obtained from several sugarcane growers in the EAA and from dealers servicing producers in mid 2003.

\section{Yields}

The review of the literature conducted by Savant, et al. (1999) included research results showing wide ranges of yield increases (5-50\%) in both tonnage and sugar due to silicon applications.

A conservative $10 \%$ yield increase in the plant cane and stubble cane crops translates into 4.0 net tons of sugarcane per acre ( 0.43 tons of sugar) and 3.5 net tons of sugarcane per acre ( 0.376 ton of sugar) for the plant cane crop and first ratoon, respectively. If the average market price for sugar received by the mill is set at $\$ 440$ per ton, then the extra gross revenue for the plant cane amounts to $\$ 189.20$ per acre. The silicon cost is $\$ 96.27$ per acre. Additional costs include mechanically harvesting the extra sugarcane produced ( $\$ 5.45$ per ton of sugarcane) and milling it ( $\$ 120$ per ton of raw sugar produced). These costs amount to $\$ 21.80$ per acre and $\$ 51.60$ per acre, respectively. Therefore the plant cane crop's extra net revenue is $\$ 19.23$ per acre. Since revenues are not received after 1.5 years, net revenues need to be discounted to their net present value using the $\$ 1(1+\mathrm{i})^{-\mathrm{n}}=\$ 1(1+0.08)^{-1.5}=0.891$ formula, where $i=$ interest rate $(8 \%)$ for discounting income and $n=$ number of years (1.5) until income is received, or $\$ 17.13$ per acre $(\$ 19.23 \times 0.891)$. 
For the first stubble cane crop, the $10 \%$ increase in yield represents an additional 0.376 ton sugar per acre, which translates into a gross revenue of $\$ 165.44$ per acre. No silicon cost is involved in this case. The cost of mechanically harvesting the sugarcane and milling the extra sugarcane are $\$ 19.07$ per acre and $\$ 45.12$ per acre, respectively. Therefore, the net revenue for the first stubble cane crop is $\$ 101.25$ per acre. As in the plant cane crop, calculating the extra net revenue for the first stubble cane crop requires using the $\$ 1(1+\mathrm{i})^{-\mathrm{n}}=\$ 1(1+0.08)^{-2.5}=0.825$ present-value formula, where $i=8 \%$ and $n=2.5$ years, or $\$ 83.53$ per acre $(\$ 101.25 \times 0.825)$. The total extra net revenues are $\$ 100.66$ per acre $(\$ 17.13+$ \$83.53) [Table 2].

\section{Other Benefits}

Many other benefits are reported in the literature (Datnoff, et al., 2001). They include disease control (lower rust and ring spot damage), insect control (reduction in borer populations), decrease in toxicity levels, freeze alleviation, water-use efficiency, lodging reduction, and erectness improvement. Another important benefit of silicon application includes its role in the synthesis, storage, and retention of sucrose in the sugarcane plant. In addition, the extra associated costs attributable to silicates in the sugarcane arriving at the mill. These benefits and costs must be quantified to perform the corresponding economic analysis.

\section{Benefits and Costs for Rice-Sugarcane Rotation Production}

The first two sections on benefits and costs have demonstrated that silicon applications should be feasible in the EAA when these two crops are grown in a monoculture production system. But what about in rice-sugarcane rotation production? The problem of when, if ever, to apply silicon becomes an economic one for three reasons. First, both rice and sugarcane respond to pre-plant applications of silicon, with residual effects in rice-sugarcane rotation. Second, there are unequal gross and net returns per hectare for each crop. Third, both material and application costs are high. Furthermore, the material application has a direct impact on the timing of the investment and the expected returns it generates in the future. Commodity prices are different, as are the harvest and post-harvest costs associated with the extra production generated from silicon applications.

The original version of this analysis (Alvarez, et al., 1988) presented an economic analysis of the two silicon applications (rice and sugarcane) in the three production systems of the EAA (before rice, before sugarcane, and before rice-sugarcane). Since the two monoculture examples have already been discussed, this section only deals with the before rice-sugarcane rotation production system.

\section{Methodology}

A detailed description of the methodology can be found in Alvarez, et al. (1988). The equations relating silicon application to both rice and sugar yields were developed by Anderson, et al. (1987). Maximum physical output was calculated from those equations and substituted into a profit equation. Solving for the silicon variable provided the equation for the optimal rate of calcium silicate.

The price of U.S. No. 2 rough rice was set at $\$ 200$ per ton. The cost of the calcium silicate was $\$ 38$ per ton, including application. The additional cost of harvesting, hauling, and drying the exta rice produced was estimated at $\$ 40$ per ton, which was then multiplied by 1.106 to convert it from wet- to dry-weight, resulting in a cost of $\$ 44.25$ per ton. The average market price of sugar received by a mill was $\$ 400$ per ton. The cost of harvesting and hauling the extra sugar produced was estimated at $\$ 90$ per ton, which is equivalent to $\$ 10.75$ per gross ton of sugarcane. For both computations, equations in Alvarez and Rohrman (1984) were used, assuming a $5 \%$ trash content per gross ton and a $14.25 \%$ sucrose content for normal juice. Discounting was done at $10 \%$ for 1.5 years.

\section{Results and Discussion}

The results show that, under the cost and price structures assumed in this example, the amount of silicon to be applied should be 4.4 tons per acre. Such applications generate a net return of $\$ 92$ per acre for both rice and sugar. As previously discussed, all other benefits should also be considered. 


\section{References}

Alvarez, José, and G.H. Gascho. 1979. Calcium Silicate Slag for Sugar Cane in Florida. II. Economic Sugar y Azúcar 74(8, August):32,34-35.

Alvarez, José, and Lawrence E. Datnoff. 2001a. The Economic Potential of Silicon for Integrated and Sustainable Rice Production. Crop Protection 20:43-48.

Alvarez, José, and Lawrence E. Datnoff. 2001b. The Economics of Silicon for Integrated Management Sustainable Production of Rice and Sugarcane. In Silicon in Agriculture, edited by L.E. Datnoff, G.H. Snyder and G.H. Korndorfer, pp. 221-239.

Amsterdam: Elsevier Science.

Alvarez, J., and F. Rohrman. 1984. Relationships Among Various Measures of Sugar Quality. EREC Research Report EV-1984-10, Everglades Research and Education Center, University of Florida, Belle Glade, FL.

Alvarez, J., G.H. Snyder, D.L. Anderson, and D.B. Jones. 1988. Economics of Calcium Silicate Slag in a Rice-Sugarcane Rotation in the Everglades. Agricultural Systems 28(3):179-188.

Anderson, D.L., D.B. Jones, and G.H. Snyder. 1987. Response of a Rice-Sugarcane Rotation to Silicate Slag on Everglades Histosols. Agronomy Journal 79:531-535.

Anonymous. 1997. Silicon-Enriched Soil Boosts Rice Yields. UF/IFAS Newsline: South Florida UF/IFAS Research and Education 3:4-5.

Datnoff, L.E., C.W. Deren, and G.H. Snyder. 1997. Silicon Fertilization for Disease Management of in Florida. Crop Protection 16:525-531.

Datnoff, L.E., G.H. Snyder, and G.H. Korndorfer. 2001. Silicon in Agriculture. Amsterdam: Elsevier Science.

Epstein, Emanuel. 2001. Silicon in Plants: Facts vs. Concepts. 2001. In Silicon in Agriculture, edited by L.E. Datnoff, G.H. Snyder and G.H. Korndorfer, pp. 221-239. Amsterdam: Elsevier Science.
Savant, N.K., G.H. Snyder, and L.E. Datnoff. 1997. Silicon Management and Sustainable Rice. Advances in Agronomy 58:151-199.

Savant, N.K., G.H. Korndorfer, L.E. Datnoff, and G.H. Snyder. 1999. Silicon Nutrition and Production. Journal of Plant Nutrition 22:1853-1903. 
Table 1. Summary of extra revenues and costs due to silicon application in the rice monoculture.

\begin{tabular}{|lrrr|}
\hline \hline Item & Plant Crop & First Ratoon & Totals \\
\hline Gross Revenue & & dollar per acre & \\
Silicon Cost & 59.40 & 59.40 & 0 \\
Harvesting Cost & 48.50 & 1.13 & \\
Net Revenue & 1.13 & 58.27 & \\
Discounted Net Revenue & 9.77 & 51.92 & 61.69 \\
& 0.00 & & 60.45 \\
Net Revenue and Cost Savings & & & 22.30 \\
\hline Total Net Revenue & & & \\
$\quad$ Savings in Fugicide Applications & & & 152.94 \\
$\quad$ Returns from Better Grain Appearance & & & \\
$\quad$ Savings in Insecticide Applications & & & \\
$\quad$ Total Added Net Returns & & & \\
\end{tabular}

Table 2. Summary of extra revenues and costs from yield increases due to silicon application in the sugarcane monoculture.

\begin{tabular}{lrr}
\hline \hline Item & Year 1 & Year 2 \\
\hline & & dollars per acre \\
Gross Revenue & 189.20 & 165.44 \\
Silicon Cost & 96.57 & 0 \\
Harvesting Cost & 21.80 & 19.07 \\
Milling Cost & 51.60 & 45.12 \\
Net Revenue & 19.23 & 101.25 \\
Discounted Net Revenue & 17.13 & 83.53 \\
\hline \hline
\end{tabular}

